\title{
BUILDING PARTNERSHIP AND GOOD GOVERNANCE IN CORPORATE SOCIAL RESPONSIBILITY
}

\author{
Heryani Agustina ${ }^{1)}$ \\ 1) Swadaya Gunung Jati University Cirebon \\ Email : heryaniagustina28@gmail.com
}

\begin{abstract}
Corporate Social Responsibility (CSR) practice in local area involved three governance components that are local government, private sector and society, so productive and strong partnership among those three components need to be built in order to create good governance in CSR. Partnership and good governance in CSR will create synergy and optimal CSR results, so it supports local government programs to create society prosperity. Some area success in building partnership and good governance in CSR, but there are many areas are failed and involved in corruption case of CSR fund. Building partnership and good governance in CSR is not an easy thing because it faced many obstacles related to basic foundation of partnership and good governance itself.
\end{abstract}

Keywords: Partnership, Good Governance, Corporate Social Responsibility

\section{INTRODUCTION}

Main duty of local government is giving public service. But, because of local government limitation, the practice of public service cannot be done all by local government but also by private sector. Private sector role in public service recently is more important and wider along with the growth of society demand and needs. Public service by private sector can be done with many patterns that are done autonomically by private sector itself or by contract system, coordination, partnership and collaboration with local government.

Private sector is one of important economy actors. As the economy actor, main orientation of private sector is profit oriented. Private sector also will affect society and environment, so they are demanded to give useful contribution for society. This is implemented in the form of Corporate Social Responsibility (CSR) or company's Social and Environment Responsibility (SER).

CSR activity in many areas in Indonesia is generally focused on education, health, economy and health area. In education area it is done in the form of scholarship, foster kid program, education assistance for poor students, etc. In health area it is done in form of free medication, mass circumcision, etc. In economy area it is done in form of society economic empowerment, partnership with small and medium businessmen, giving capital for business, etc. In environment area it is done in form of replanting trees, dirty house renovation, giving cleanliness facility (rubbish bin), etc.

CSR in Indonesia is arranged in Law Number 40/2007 about Limited Liability Company and Government Decree Number 47/2012 about Social and Environment Responsibility (SER) of Limited Liability Company.
According to Law Number 40/2007, SER or CSR is commitment of company to get involved in continuous economic development for improving quality of life and useful environment, for the company itself, local community, and society in general. Besides those rules, some areas in Indonesia have Local Rules that arrange CSR. In those local rules there is also sanction for company that does not do CSR.

CSR arrangement by central government or local government is the implementation of government function as regulator, dynamist, and facilitator of development. This arrangement is important to guarantee that CSR is done by company. Besides that, CSR benefit recipient is the same as recipient of local development benefit that is society. That's why local government is concerned to CSR because CSR is expected to support local development done by local government.

CSR in local area involved three components in governance that are local government, private sector and society. That's why productive and strong partnership is needed to be built among those three components to create good governance in CSR. Through partnership of those three components it is expected that CSR can be worked optimally, so it supports the improvement of society prosperity that become the goal of local government practice. This paper will analyze partnership concept and good governance in public administration, CSR concept in continuous development perspective, implementation of partnership and good governance in CSR in Indonesia, and obstacles faced in partnership and good governance. 


\section{METHODS}

Research in order to collect data for this paper is done by using qualitative approach. According to Creswell (2014), qualitative research is a method to explore and understand the meaning that---by some individuals or group---is considered come from social and humanity problems.

Data in this research is collected from literature study by learning many relevant literatures, in the form of books, scientific journals, rules of law and data and information from internet.students.

\section{DISCUSSION}

\section{Partnership Concept and Good Governance in Public Administration}

Recently public administration has developed from Old Public Administration (OPA) into Contemporary Public Administration. According to Thoha (2014) OPA focus on service given directly by government institutions. This direct government service is called direct public administration (Shafritz and Hyde, 1997) or direct government production (Donahue \& Zeckhauser, 2011) or direct operation (Swerdlow in Tjokroamidjojo, 1996). All those terms mean that government does public service by himself and it is not given to private sector.

Classical paradigm like this now has been abandoned since the born of contemporary public administration paradigm in the form of New Public Administration (NPA), New Public Management (NPM) and New Public Service (NPS). NPA focus on social justice, decentralization, delegation, and participation (Frederickson, 1987). NPM focus on public content that no longer meant as country but must be meant as collaboration of government, society and businessman (Hughes, 1994). NPS focus on other power outside government, so there is role balance in creating service suitable with society expectation (Rusli, 2015). Organization structure in NPS is collaborative structure between external and internal leadership (Denhardt \& Denhardt, 2003).

Other contemporary public administration paradigm is good governance that is the best form of governance. Governance is set of efforts to coordinate and monitor activity that can maintain collaborative in partnership or institution (Bryson, et.al., 2006). Governance involved not only government and country, but also role of many actors outside government and country, so the sector that get involved is wide (Widodo, 2001). Governance is focused on governing function practice together with government and other institutions, NGO, private company or citizen (Wibawa, 2014). Governance model more related with cooperative rather than state/government intervention, where state and non state actors participate in mixed policy network between public and private (Kenis \& Schneider in Thompson \& Pforr, 2015).

According to UNDP (1997), governance has three components or domains that are state, private sector and society. According to Wasistiono (2012), relationship among those three components is not hierarchy but heterarchy that there is position equality and only different from their function. In governance, the one who has important role is not government but all components have the role suitable with their function. In developing country where private sector and society sector relatively is not good enough, government sector must have important role. Government sector must act as development supervisor. In the end if the private sector and society sector is getting better because of the development, government sector role reduce slowly.

Reduction of government role is because of so many government duties given to private sector and society sector through privatization, coordination, contract, partnership, collaboration, etc. Partnership one of many models implemented in public administration practice recently. This is stated by Rondinelli (2003) that recently there are many government programs and public problems done by PublicPrivate Partnership models or partnership between public sector (government) and private sector. This partnership practice according to Shafritz and Hyde (1997) is one of indirect public administration forms.

Partnership is process that involved cross organization combination and interest coalition that cover joined goals and agenda as tool to response gossip or to create certain outcome (Suripto, 2015). Partnership is two way relations that have equal or balance power characteristic with interaction accommodate benefit that directed to get joined goals (Moseley in Suripto, 2015). Partnership is formal program that created by top-down approach and not spontaneous developed from bottom. Partnership model characteristic is that partners from many involved sides cannot be equal (Booxmeer and Beckhoven in Suripto, 2015).

Osborne (Suripto, 2015) stated the characteristic of partnership are:

1. Government and private organization is involved in decision making and joined production.

2. Both sides are involved in the first joined process in order to create and develop joined product that contributed to both interests.

3. Partnership benefit is very considered effectiveness that getting increased (the measurement is synergy and output enrichment).

4. Success key is a goal knit, doing rules for on going interaction, developing rules and job that considered efforts and joined commitment creation.

5. Based on process management principles because of common goal, cost art, realization and usage still kept as subject to joined decision making.

6. Reverseable trust is important thing to make relationship longer among partners who kept interests, working ways, accountability, and their financial principles.

According to Suripto (2015), characteristics of partnership are:

1. Partnership involved cross organization relationship and coordination, government and non-government institutions. 
2. Public-private partnership is formed to achieve many goals, such as solving public problems by producing and providing public goods and service.

3. Partnership can be differentiated in one continuous line from weak partnership to strong partnership. Weak partnership has characteristic of decisions, cost, and concentrated risk in one or few actors involved, while strong partnership is characterized by joined decisions, costs and risk.

4. Partnership involved synergy principles and norms, output enrichment and trust.

Partnership done with synergy by those three components, governance will create good governance. According to UNDP (1997) characteristics and principles of good governance are: participation, rule of law, transparency, responsiveness, consensus orientation, equity, effectiveness and efficiency, accountability, and strategic vision. Those nine characteristics or principles are interrelated that are strengthen each other, mutually reinforcing and cannot be independent. For example, if the information is easy to access, it means that government transparency is getting better, participation level is getting wider, and decision making process is getting effective. According to Sartono (2011), to create good governance needed strong public bureaucrat leader who has characteristic of visionary, integrationist, empowerist, ratioemotion controller, and integrity.

\section{CSR Concept in Sustainable Development Perspective}

Corporate Social Responsibility (CSR) or company social and environment responsibility (SER) is a concept that company has many responsibility forms to all stakeholders or other interest owner, that are consumer, employee, stakeholder, community (society group), and environment in all company operational aspects that covers economy, social and environment aspects (id.wikipedia.org). Social responsibility is based on reality that no single organization that can grow without support and trust from its environment. Social responsibility can be done in the form of labors use, the empowerment of society as supplier of raw material, involvement in social activity, supplier of public facility, and participate actively in society development (Siagian, 2000).

CSR development cannot be separated from sustainability development. According to The World Commission On Environment and Development that is known as The Brundtland Comission, sustainable development is development that fulfill human need without sacrificing future generation ability in fulfilling their need (Solihin, 2009).

According to World Bank, CSR done by company related to sustainable development. This is because company activity not only affect the internal environment in the form of profit achievement and employee prosperity, but also affect the external environment that are society and environment (Dartey-Baah, et.al., 2010). Company is central point in sustainable development. This is because of company activity not only affect financial and organization cultural aspects of the company, but also create social and environment effect caused by company activity, both in short and long term (Aras \& Crowther, 2007).
Elkington (Wibisono, 2007) made theory of triple bottom line in CSR that if company want to be sustainable, it should aware of 3P; profit, people and planet. In 3P context, company not only pursue profit, but also consider and get involved in fulfillment of society prosperity (people) and actively contribute in keeping environment preservation (planet).

Caroll (1991) created theory of "The Four-Part Model of Corporate Social Responsibility" that considered CSR as a concept consists of four responsibilities related to each other, that are:

1. Economic responsibility, company must get profit in order to give reward to stakeholders, pay employee, and produce qualified products suitable with consumers' expectation. This economic responsibility is a base for all next responsibility.

2. Legal responsibility, company must obey the existing law and rules.

3. Ethical responsibility, company must do ethically, well, fairly and properly.

4. Philantropic responsibility, company must become good citizen in giving contribution that directly felt by society to improve society quality of life. CSR in the form of this philantropic responsibility is wellknown by Indonesian society.

\section{Partnership Implementation and Good Governance in CSR in Indonesia}

Rules about CSR or SER in Indonesia explicitly stated in Law Number 40/2007 about Limited Liability Company that arrange the duty to do SER for company that the business is in or related to natural resources. That Law is technically arranged in Government Decree Number 47/2012 about Limited Liability Company SER, that arrange the duty to do SER for company that has business in or related to natural resources. Then there is Social Affairs Minister Decree Number 13/2012 about Business World SER Forum in Social Prosperity Practice. The forum is in province level and established to help Minister of Social Affairs and governor in optimalizing social responsibility practice of business world in social prosperity practice.

Before those rules, CSR or SER have been arranged in many Laws, that are:

1. Law Number 22/2001 about Petroleum and Natural Gas, it is arranged about coordination contract that must contain main rules: society development and traditional society rights guarantee.

2. Minister of National State Business Organization Decree Number Per-05/MBU/2007 about Partnership Program and Community Development (PPCD) that specialized for National State Business Organization.

3. Law Number 25/2007 about Capital Investment that decided every investor must do SER.

4. Law Number 13/2011 about Handling the Poor, decided that every businessman gets involved in providing fund for society development as the social responsibility for handling the poor. 
Since Government Decree Number 47/2012 about SER of Limited Liability Company is issued, many areas in Indonesia issued Local Government Decree about SER. Until the end of 2016, at least there are 90 Local Government Decree about SER that consist of 15 Privince Decree, 59 Regency Decree and 16 City Decree (www.republika.co.id).

The presence of those decree showed that one of good governance principles, rule of law, has been fulfilled. But the thing that is more important is how company implements those rules consequently and consistently. According to Corporate Forum for Community Development (CFCD), not all companies in Indonesia do CSR well, even though they are capable of. Many companies have not realized the importance of doing CSR program. But when their business is facing problem with local society, then they realize about it. CSR is not only for erasing mistake done by company by giving reward to surrounding society, because CSR program is considered success if it can empower society (surabaya.bisnis.com). Besides that, legal enforcement to the company that does not do CSR is weak even though in CSR rules there is sanction for the company that disobey it.

CSR practice in local area involved three components of governance, that are local government, private company, and society. According to Wibisono (2007), there are some facts about the importance of relationship between company and government, they are:

1. Business world is government partner to manage resources since it is impossible for government to manage all resources.

2. Business world helps government in turning economic wheel and supporting development.

3. Business world gives income to government in the form of retribution tax. The bigger the business is, the bigger tax given to government

According to Wibisono (2007), partnership done by company and government and society can direct to three patterns:

1. Contra productive partnership pattern. This pattern happened if the company try to get the biggest profit for shareholders, while the relationship with government and society is just a theory. Company runs with its own target, government does not care about it, while society does not have any access to the company. This relationship is beneficial only for some people, for example government officer or street person in society, so what is important for the company is short term safety. In this scenario partnership can be done but it is vague and even emerge negative impression and trigger bad phenomenon such as worker strike, demonstration by society, environment pollution, excessive natural resources exploitation, and even the closure of the company.

2. Semiproductive partnership pattern. In this pattern, government and society are considered as object and problem outside company. Company does not know government programs, government also does not give conducive atmosphere to business world and society is passive. This partnership pattern still refers to short term interest and does not create sense of belonging in society and low benefit in government. Coordination purpose more public relation, where government and society is considered as object. In other words, partnership is not strategic yet and still a purpose self interest, company, not common interest between company and its partner.

3. Productive partnership pattern. This pattern put partner as subject and is in common interest paradigm and there is mutual symbiosis. Company has high social and environment awareness, government gives conducive atmosphere for business world, and society gives positive support to company. And even partner can be given a chance to be part of shareholders, for example get shares through stock ownership program.

Partnership pattern that must be built in CSR in local area is productive partnership. In contemporary public administration perspective, productive partnership is strong partnership characterized with decisions, costs, and risks that are guaranteed together (Suripto, 2015). In this strong or productive partnership, local government create conducive atmosphere for company, private company provide CSR fund for many development activities, while society use and preserve development result from that CSR fund.

One area that is considered success in implementing strong or productive partnership pattern between local government, private sector, and society is Bandung. In 2016, Bandung received CSR fund 32 billions rupiah from 194 private companies that is used for 180 activities, physical and non physical through Bandung SER. This forum is formed by Bandung government to collect, manage, distribute and evaluate SER fund in Bandung. The forum consists of government and stakeholders of Bandung development, including private sector, academician, and institution (www.pikiran-rakyat.com).

According to Bandung Mayor, Ridwan Kamil, if only rely on Local Government Budget, development growth is only $2,5 \%$. That's why private sector is invited to get involved in development. With the coordination between government and private sector will fasten development pace in Bandung. One of the programs that can be an example of collaboration in successful SER is development of Ujung Berung city square that now become family recreation place in east Bandung. The design of that city square is made by society with the supervision from Mayor, that city square development fund is from SER fund of private company, and the management of city square is done by every sub-district (www.pikiran-rakyat.com).

In strong and productive partnership means participation has been built well, so there is efficiency and effectiveness in CSR. With participation, efficiency and effectiveness showed good governance in CSR has been built well. That strong and productive partnership is a part of local government leadership that suitable with good governance principles that has strategic and responsive vision to the society needs, so local government can be the integrationist 
and empowerist all components involved in CSR. Strong and productive partnership and visionary leadership can create CSR management, that suitable with good governance principles that are done fairly, transparently, and accountably.

Partnership and good governance description in CSR is still a dream for many areas. Partnership and good governance in CSR in local area has not implemented very well yet. In contrast, in CSR program often found two opposite sides and throw the responsibility between local government and company. Local government often thinks that every problem in society is the result of company activity, so it must be finished by the company. In contrast, company thinks that resolution is responsibility of local government. This condition showed that good governance principle that is consensus orientation has not been built yet.

In many areas, CSR program is not synergy and along with local government programs because company done more CSR without involving government. The effect is there is overlapping, so there is no justice and even distribution. Besides that, CSR often in the form giving fund, physical facility, but less priority in society empowerment. This caused the benefits of CSR are only temporary or pragmatic, so it is not sustainable. The philosophy that becomes the foundation of CSR is "giving fish", not "giving the hook". This philosophy is not suitable with society empowerment principles that should be the priority in CSR.

CSR fund management in many areas also has many problems because it is not transparent and accountable. Commission for Corruption itself reminds government to be careful in using CSR fund because it is sensitive to corruption (www.solopos.com). Corruption of CSR fund happened in many areas, for example: (1) CSR fund corruption 11,7 billions rupiah that involved governor of Middle Sulawesi in 2016 (nasional.tempo.co), (2) allegation of CSR fund corruption from hundreds of company in Jakarta that involved Governor Ahok during 2015-2017 (www.kompasiana.com), (3) CSR fund corruption 1,5 billions rupiah in the form of football club assistance that involved Cilegon Mayor in 2017 (national.kompas.com), (4) CSR fund corruption 50 billions rupiah by Halmahera Regent in 2007-2017 (rri.co.id), (5) CSR fund corruption 3 billions rupiah that involved Vice President of Local House of People Representatives Majalengka Regency in 2016 (www.radarcirebon.com), etc. Those CSR fund corruption cause many businessmen feel objection if CSR fund is managed by local government (kliklegal.com).

\section{Obstacles in Implementing Partnership and Good Governance in CSR in Indonesia}

Partnership is a pattern implemented in Indonesia, including in CSR. But, the proof showed that partnership is successful in developed country, but that success has not proven in developing country like Indonesia. Some research clearly describe that partnership in Indonesia is not successful and do not do transparently and accountably. The main cause for this failure is rule that is not really enforced. Other cause is competency and capability of legislative, executive and private institution that in not enough, unsupported culture and corruption, collusion and nepotism spread uncontrollable (Suripto, 2015).

In CSR implementation that involved local government, private sector, and society, there should be strong and productive partnership and tough good governance, so CSR result can support local development program. But, building partnership and good governance in CSR is not easy because it faced many obstacles, such as:

1. Lack of commitment and awareness of company leader about CSR importance for company continuity and for society interest and environment preservation.

2. CSR activity still consists of activity to build company image.

3. Solid common commitment and consensus between local government and company about CSR that has not implemented yet.

4. Weak leadership of local government head that is not visionary and innovative and not able to do his role as motivator, empowerist and integrationist of the sectors involved in CSR.

5. CSR fund management is not done transparently and accountably, so CSR fund is sensitive to corruption.

6. Weak legal enforcement for company that do not do CSR, while the sanction is arranged in rules of law.

7. Weak local government institution capacity as facilitator and dynamist in doing CSR.

8. Weak CSR Forum institution capacity as group of communication, consultation and evaluation in CSR practice.

Weak company institution capacity in planning, doing and managing CSR.

\section{CONCLUSION}

CSR practice in local area involved three components in governance that are local government, private sector, and society, so in CSR practice it needs to be built productive and strong partnership among those three governance components. Productive and solid partnership need to be created to implement good governance in CSR that cover participation, rule of law, transparency, responsiveness, concensus orientation, equity, effectiveness and efficiency, accountability, and strategic vision.

Partnership and good governance in CSR will create CSR results that along with and synergy, so it supports local government programs in order to create society prosperity that become the goal of local government practice. Some areas has success in building partnership and good governance in CSR, but there are many areas that are failed and even involved in CSR fund corruption.

Building partnership and good governance in CSR is not easy because it faced many obstacles. Those obstacles related to basic foundation of partnership and good governance that is lack of commitment and awareness of company leader, common commitment and concensus between government and company that is not implemented yet, CSR fund management that is not transparent accountable, weak local government leadership, weak legal 
enforcement, and weak local government institution capacity, CSR forum and company.

\section{REFERENCES}

Aras, Guler \& David Crowther. 2007. Sustainable Corporate Social Responsibility and the Value Chain. Dalam David Crowther and M.M. Zain (eds.). New Perspectives on Corporate Social Responsibility. Sage Publication, Inc

Bryson, John M., Barbara C. Crosby \& Melissa Muddleton Stone. 2006. The Design and Implementation of Cross-Sector Collaborations: Propositions form the Literature. Public Administration Review. 66:44-55. New Jersey: John Wiley \& Sons

Carrol, Archie B. 1991. The Pyramid of Corporate Social Responsibility: Toward the Moral Management of Organizational Stakeholders. Business Horizons. Vol. 34 No. 4.

Cresswell, John W. 2014. Research Design. Pendekatan Kualitatif, Kuantitatif, dan Mixed. Yogyakarta: Pustaka Pelajar

Denhardt, Janet V. \& Robert B. Denhardt. 2003. The New Public Service: Serving Rather Than Steering. New York: ME Sharpe

Frederickson, H. George. 1987. Administrasi Negara Baru. Jakarta: LP3ES

Hughes, Owen E. 1994. Public Management and Administration: An Introduction. New York: St. Martin's Press, Inc

Rondinelli, Dennis A. 2003. Partnering for Development: Government-Private Sector Cooperation in Service Provision. Dalam "Reinventing Government for the Twenty-First Century". Editor Dennis A. Rondinelli \& G. Shabbir Cheema. Bloomfield: Kumarian Press.

Rusli, Budiman. 2015. Isu-Isu Krusial Administrasi Publik Kontemporer. Bandung: Mega Rancage.

Sartono.2011. Kepemimpinan Dalam MSDM Birokrasi Yang Good Governance. Dalam "Memahami Good Governance Dalam Perspektif Sumber Daya Manusia". Editor Ambar Teguh Sulistiyani: Yogyakarta: Gava Media

Shafritz, Jay, M. \& Albert C. Hyde. 1997. Classic of Public Administration. Florida: Harcourt Brace College Publishers

Siagian, Sondang P. 2000. Administrasi Pembangunan. Konsep, Dimensi dan Strateginya. Jakarta: Bumi Aksara

Solihin, Ismail. 2009. Corporate Social Responsibility from Charity to Sustainability. Jakarta:Salemba Empat.

Suripto. 2015. Reformasi Sektor Publik Melalui Kemitraan: Masalah atau Solusi?. Dalam Manajemen Publik Kontrmporer. Editor Subando Agus Margono \& Bevaola Kusumasari. Yogyakarta: Gava Media

Thoha, Miftah. 2014. Ilmu Administrasi Publik Kontemporer. Jakarta: Kencana

Thompson, Graham \& Christoff Pforr. 2015. Policy Network and Good Governance---A Discussion. Working
Paper Series. Curtin University of Technology School of Management

Tjokroamidjojo, Bintoro. 1996. Pengantar Administrasi Pembangunan. Jakarta: LP3ES

United Nation Development Programme (UNDP). 1997. Governance for Sustainable Human Development. New York: UNDP

Wasistiono, Sadu. 2002. Desentralisasi, Demokratisasi dan Pembentukan Good Governance. Dalam "Desentralisasi \& Otonomi Daerah. Desentralisasi, Demokratisasi \& Akuntabilitas Pemerintahan Daerah". Editor Syamsuddin Haris. Jakarta: LIPI Press.

Wibawa, Samodra. 2014. Good Governance dan Otonomi Daerah. Dalam "Mewujudkan Good Governance Melalui Pelayanan Publik". Editor Agus Dwiyanto. Yogyakarta: Gadjah Mada University Press.

Wibisono, Yusuf. 2007. Membedah Konsep dan Aplikasi CSR (Corporate Social Responsibility). Jakarta: PT. Gramedia Pustaka Utama

Widodo, Joko. 2001. Good Governance: Telaah dari Akuntabilitas dan Kontrol Birokrasi pada Era Desentralisasi dan Otonomi Daerah. Surabaya: Insan Cendikia. 